\title{
Public managers' valuation of secondary policy objectives in public procurement - results from a discrete choice experiment
}

\author{
Amandine Lerusse ${ }^{*}$, Steven Van de Walle*
}

\begin{abstract}
Governments are increasingly linking public procurement contracts to the attainment of secondary policy objectives. While not challenging the continuing dominance of price, this changes how service providers are selected. This study examines how public managers value environmental, innovative, and social goals against price in the public procurement of waste collection at the municipal level in Belgium. Using a discrete choice experiment, we study public managers' valuation of secondary policy objectives. Additionally, to extend the external validity of our findings to different administrative structures, the same study has been replicated in three other countries (Norway, Germany, and Estonia). Although price remains crucial, we observe that public managers appear to be willing to pay more to increase the environmental, innovative, and social standards of public services.
\end{abstract}

Keywords: Public procurement, Secondary policy objectives, Stated preferences, Discrete choice experiment, and Random utility theory

$\mathrm{D}$ espite the continuing dominance of price in public procurement (Fuentes-Bargues, González-Cruz, \& González-Gaya, 2017; Igarashi, De Boer, \& Michelsen, 2015; Young, Nagpal, \& Adams, 2016), governments are increasingly linking public procurement contracts to the development of secondary policy objectives (Keulemans \& Van de Walle, 2017). Whereas the primary goal of public procurement is to buy goods and services, secondary policy objectives intend to develop policies that are difficult to reach (Aldenius \& Khan, 2017; McCrudden, 2004; Morettini, 2011; Uyarra, Edler, Garcia-estevez, Georghiou, \& Yeow, 2014; Walker \& Brammer, 2009). These include the promotion of environmentally friendly policies, social justice, good governance, or public sector innovation. By considering secondary policy objectives in public procurement contracts, governments simultaneously take on the role of value creator (Mouraviev \& Kakabadse, 2015), market regulator (Jaehrling, 2015), and buyer of goods and services.

However, linking public procurement contracts to the realization of secondary policy objectives challenges how service providers were traditionally selected (Igarashi et al., 2015), creating tensions between price and secondary policy objectives (Young et al., 2016). Instead of exclusively awarding contracts to the cheapest provider, decision-makers are now forced to balance price against a multitude of secondary policy objectives. Previous research showed that the costs associated with secondary policy objectives constitute the main obstacle to their inclusion into public procurement contracts (Leal Filho, Skouloudis, Brandli, Salvia, Avila, \& RaymanBacchus, 2019; Sönnichsen \& Clement, 2019; Thomson \& Jackson, 2007; Walker \& Brammer, 2009).

In view of these previous considerations, questions have been raised about decision-makers' attitudes (Kolpakov \& Anguelov, 2020) and their valuation of secondary policy objectives against price in public

\footnotetext{
* Public Governance Institute, KU Leuven

Address correspondence to Amandine Lerusse at (amandine.lerusse@kuleuven.be)

Copyright: (C) 2020. The authors license this article under the terms of the Creative Commons Attribution 4.0

International License.
} 
procurement (Igarashi, de Boer, \& Pfuhl, 2017). Yet, Grandia and Meehan (2017) stated that few studies have examined "how public procurers deal with the (often conflicting) goals that they have to combine in their procurement" (p. 303). Past research also highlighted that decision-makers' behavior plays a major role in the implementation of secondary policy objectives (Grandia, 2016; Grandia, Steijn, \& Kuipers, 2015). However, in their systematic review of the public procurement literature, Trammell, Abutabenjeh, and Dimand (2019) found very limited empirical work examining decision-makers' attitudes in public procurement.

In light of these previous observations, this study investigates how public managers value secondary policy objectives (namely environmental, innovative, and social goals) against price when awarding contracts to service providers. It also identifies how much money public managers are willing to pay for secondary policy objectives. Although EU legislation allows governments to take secondary policy objectives into consideration, it has been observed that committed public officials are needed if one wants to further implement secondary policy objectives into public procurement (Hall, Löfgren, \& Peters, 2016). As public managers' willingness to consider secondary policy objectives is quite crucial for their implementation in public procurement, we argue that it is fundamental to research individuals' stated preferences for the secondary policy objectives by examining how they value them.

We use a discrete choice experiment focusing on contracting with waste collection firms at the municipal level in Belgium and we surveyed the heads of the environmental department of Belgian municipalities. To strengthen the external validity of our research, we replicated our study in three other countries with different administrative contexts. We examined the discrete choice data by conducting a conditional (fixed effects) logistic regression and a marginal willingness to pay analysis.

This article is divided into four sections. The first section reviews the literature on decision- makers' attitudes towards secondary policy objectives. The second section describes the study data and method. The penultimate section presents the empirical results. The last section discusses the implications of our findings, the limitations, and avenues for future studies.

\section{Decision-makers' Attitudes towards Secondary Policy Objectives}

The awarding of contracts is a typical field of decision-making in public administration. Decision-makers who have to choose, on behalf of their institutions, between competing service providers make use of a decision rule to process the information they have at their disposal. Although the literature has paid limited attention to this phenomenon (Kolpakov \& Anguelov, 2020), several studies have examined decision-makers' attitudes towards secondary policy objectives.

In their research investigating the role of psychological barriers in public procurement, Preuss and Walker (2011) found that decision-makers' cognitive and affective characteristics influence the inclusion of secondary policy objectives in public procurement. They observed that the amount of information processed by decisionmakers, a lack of training and knowledge, and different levels of motivations were all identified as obstacles to the attainment of secondary policy objectives in public procurement. Similarly, Cooper, Frank, and Kemp (2000) found that a lack of skills, training, and knowledge was associated with a low uptake of secondary policy objectives. In a similar vein, Testa, Iraldo, Frey, and Daddi (2012) highlight the importance of expertise in secondary policy objectives for their practical implementation.

Drawing on the theory of street-level bureaucrats, Hall et al. (2016) analyze the factors favoring and preventing street-level procurement officers' choice for environmental criteria in public procurement. In line with street-level bureaucracy theory, they argue that "bureaucratic discretion under conditions of limited knowledge probably has the effect of adhering to available regulation or to other forms of regulatory practices" (Hall et al., 2016, p. 472). They found that the most important barriers to the inclusion of environmental criteria in public procurement are the lack of human resources, the lack of regulations with respect to environmental criteria, and the lack of political salience. In contrast, they identify centralization, political and administrative commitment, and support from national structures as facilitating the take-up of environmental criteria in public procurement (Hall et al., 2016).

Other studies also identified decision-makers' inertia to be an important barrier to the realization of secondary policy objectives (Alberg Mosgaard, 2015; Walker, Di Sisto, \& McBain, 2008). Alberg Mosgaard (2015) argued that decision-makers are acquiring knowledge during their everyday practice, and that their attitudes 
towards secondary policy objectives depend on whether they are willing to put this knowledge into practice. Knowledge is therefore considered, in this context, as habit forming. Based on organizational change theory, Grandia, Steijn, and Kuipers (2015) found that decision-makers' affective commitment to change (the level of belief in the benefit that secondary policy objectives can possibly bring) was positively associated with the attainment of secondary policy objectives. They also identified that the degree of procedural justice - whether decision-makers judged public procurement procedures to be just - was positively connected to the realization of secondary policy objectives.

Due to the increased complexity of including secondary policy objectives in public procurement contracts, a section of the literature assumes that decision-makers do not have access to the necessary information (such as the quality of the environmental, innovative, and social objectives delivered by the supplier) to select the service provider that will best maximize the utility of their institutions (de Boer, 2017; Igarashi et al., 2015, 2017). In line with Herbert Simon (1955), these studies argue that decision-makers make use of simple decisionmaking procedures, called heuristics, to choose the service provider that will best satisfice them (de Boer, 2017; Igarashi et al., 2015, 2017). They consequently posit that decision-makers can be identified as satisficers who intend to opt for a satisfying option instead of the solution that will maximize the utility of their institutions. Yet, Kolpakov and Anguelov (2020) observed that incremental decision-making was more likely to take place in social services while rational decision-making was more likely to happen in technical services.

Although this literature has contributed to a better understanding of decision-makers' attitudes towards secondary policy objectives, it suffers from a number of limitations that our study aims at addressing. First, these previous studies exclusively analyze decision-makers' attitudes towards environmental and social criteria, but do not pay attention to innovation-related criteria. By simultaneously studying decision-makers' valuation of environmental, innovative, and social goals, our research intends to develop a more comprehensive understanding of decision-makers' valuation of a full range of secondary policy objectives. Second, experimental research in the field of public procurement is scarce as past studies have mainly examined decision-makers' attitudes towards secondary policy objectives through interviews and survey questionnaires. Our research examines decision-makers' attitudes through a different methodological approach by conducting a discrete choice experiment. Additionally, to the best of our knowledge, our study is the first that aims at quantifying, in monetary terms, decision-makers' stated preferences towards secondary policy objectives.

\section{Data \& Method}

We conducted a discrete choice experiment (DCE) to examine how public managers value secondary policy objectives against price. This stated preferences method, built on random utility theory, asks participants to choose, given a hypothetical scenario, their preferred option across several choice sets. Each choice set contains two or more options described by a combination of attributes which can take different levels. Additionally, by including a monetary attribute in the DCE, we are able to directly identify the relative impact of each secondary policy objective on decision-makers' choice (Lancsar \& Louviere, 2008).

\section{DCE Assumptions}

Random utility theory, the theoretical foundation of DCEs, postulates that decision-makers' latent preferences, also called latent utilities, are associated with all choices examined by decision-makers, and exist for all individuals (Louviere, Flynn, \& Carson, 2010). These stated preferences are composed of an observed and a random component. The observed component is composed of all the observable factors that influence decision-makers' choices such as the covariates and the attributes. The unobserved component consists of all the undetermined variables that are also affecting decision-makers' choices but that researchers are not capable of observing such as unobserved attributes, unobserved taste variations, measurement errors, or instrumental variables (BenAkiva \& Lerman, 1985; Louviere et al., 2010). It is worth noting that random utility theory remains consistent with neoclassical economic theory and considers individuals to be rational and utility-maximizers (Manski, 1977).

Yet, some limitations inherent to DCEs need to be highlighted. First, in DCEs, a limited number of attributes are assessed by participants. However, some of them might evaluate the alternatives based on another set of 'invisible' factors, resulting in some endogeneity issues. We dealt with this potential endogeneity issue 
stemming from omitted attributes by instructing participants, before they had to assess the choice sets, to assume that the non-described characteristics are the same for every firm (Lancsar \& Louviere, 2006). Whereas we do not fully eliminate the risk that participants may have ignored this instruction (Guevara \& Polanco, 2016), we claim, following Lancsar and Louviere (2006), that instructing participants not to consider other attributes decreases the risk of omitted variables bias.

Second, participants might show some social desirability bias while assessing the choice tasks by selecting the alternative that is the most socially desirable rather than the one that they would choose in a real-life setting. This social desirability bias could lead to an upward estimation of the coefficients (Klesges, Baranowski, Beech, Cullen, Murray, Rochon, \& Pratt, 2004). In light of this limitation inherent to DCEs, we stress that we are examining public managers' stated preferences, that can be prone to biases, rather than revealed preferences. Our conclusions should therefore be interpreted carefully.

A related limitation has been identified in the literature as the hypothetical bias. As DCEs have hypothetical scenarios, participants tend to overstate their stated preferences (or marginal willingness to pay). However, some scholars argue that "hypothetical bias tends to arise most commonly when valuing distant, complex, and unfamiliar goods and services" (OECD, 2018, p. 104). In the present study, public managers are used to evaluating tender documents, and should therefore be less prone to hypothetical bias than individuals who evaluate goods and services with which they are not familiar.

\section{Experimental Design}

The DCE focuses on public managers' stated preferences for secondary policy objectives in waste collection at the municipal level in Belgium. We selected waste collection as this is one of the most fundamental and apparent public services where contracting out with private firms is relatively common. In the waste collection field, we focus more specifically on the door-to-door collection of bulky waste. This specific type of municipal waste is too big to be placed in standard waste containers, and is therefore either placed on the pavement to be picked up by waste collection companies or brought to container parks. Examples of bulky waste are old furniture, mattresses, or white goods.

During the experiment, public managers are presented with a hypothetical scenario stating that their municipality has decided to have a new bulky waste collector (see Appendix A for the hypothetical scenario and the instructions). They are then asked to select which one, out of the two presented firms, should become the new bulky waste collector of their municipality. The firms are described by price, environmental, innovative, and social criteria. We concentrate on these three secondary policy objectives as the European Union has paid particular attention to linking public procurement contracts to the realization of environmental, innovative, and social goals (European Commission, 2011, 2016, 2018). In this respect, the 2014/24 EU Directive on public procurement facilitates and encourages procurers to use public procurement as a tool to develop societal objectives.

Including an environmental criterion into public procurement contracts intends to stimulate the development of greener public goods and services (Testa et al., 2012). By stimulating innovation through public procurement, governments intend to correct for market failures, meet new market needs, modernize public services, and stimulate the development of start-ups (Edler \& Georghiou, 2007; Edquist \& Zabala-Iturriagagoitia, 2012; European Commission, 2018). Including social objectives intends to create social value (Loosemore, 2016), for instance through creating employment for long-term unemployed.

\section{Operationalization of Secondary Policy Objectives}

We operationalized price and the secondary policy objectives through a two-step procedure. First, we derived a list of attributes by conducting desk research of documents concerning the implementation of environmental, innovative, and social criteria of the main waste collection companies operating in Belgium (see appendix B for the initial list of attributes). Second, we conducted six face-to-face semi-structured interviews with Belgian waste collection experts. We selected these interviewees purposively based on their experience and expertise in the field of waste collection. They also came from different management levels (i.e. waste collection agencies, intermunicipal associations, a bulky waste collection firm, and a municipality). The interviews were subdivided into two parts, and lasted for approximately one hour each. While the first part of the interview focused on questions about the organization, and the contracting out process of waste collection at the municipal level, the second 
part of the interview concentrated on the operationalization of price, environmental, innovative, and social criteria.

During this phase of the interview, the experts were asked to select the attributes and their respective levels to reflect as closely as possible the reality of the bulky waste collection market. For this purpose, we asked them to rank, from the most important to the least important, the attributes we derived from the desk research. Experts were also free to add attributes to the list when they considered that secondary policy objectives could be operationalized differently. Following the interviews, four attributes and their respective levels stood out as being the most considered by the waste collection experts; the price per ton of bulky waste collected, the age of the fleet, a mobile application, and the presence of a training scheme for long-term unemployed (see appen$\operatorname{dix} C)$.

\section{Fractional Factorial Design}

To reduce the number of possible choice sets, we performed a fractional factorial design. Lancsar and Louviere (2008, p. 667) defines it as "a sample from the full factorial selected such that all effects of interest can be estimated". We generated the fractional factorial design by computing an orthogonal main effect array with the rotation method in R (Aizaki, 2012). This type of design ensures that the attributes are statistically independent from each other (orthogonality), and that every level has the same probability of appearing throughout the choice sets (level balance) (Ryan, Kolstad, Rockers, \& Dolea, 2012). The fractional factorial design reduced the number of possible choice sets to twelve and divided them into two blocks of six choice sets each (see appendix $\mathrm{D}$ for an example of a choice set and appendix $\mathrm{E}$ for an overview of the different choice sets). Public managers were then randomly allocated to one of the two blocks and had to assess six choice sets. No significant differences between the two blocks with regards to public managers' age, gender, education, and tenure were identified, indicating that the groups are balanced (see appendix F).

\section{Sample and Data Collection}

We surveyed either the head of the environmental department or the environmental advisor of all Belgian municipalities because they are formally responsible for the procurement of waste collection services in Belgium. Based on Lancsar and Louviere's (2008, p. 670) rule of thumb stating that "one rarely requires more than 20 respondents per version to estimate reliable models", we aimed at collecting at least 20 respondents per version, leading to a minimum required sample size of 40 respondents. The DCE was administered through personalized emails to all public managers (one per municipality) for whom direct contact details were available. This resulted in a population of 546 public managers. Out of this population, 161 public managers responded to the questionnaire, indicating a response rate of 29.5 percent (see appendix $G$ for a description of the sample). The data collection started in September 2018 and ended in November 2018.

\section{External Validity Check}

We replicated our study in Estonia, Germany, and Norway to examine whether our results could be validated across different administrative structures (i.e. the Eastern European, Continental European-Federal, and Nordic administrative traditions) (Pollitt \& Bouckaert, 2017). We also selected these countries because they have all promoted strategies to include environmental, innovative, and social policy objectives into public procurement contracts in a way that is similar to Belgium (OECD, 2019).

Before distributing the DCE to the three other countries, we conducted a pilot study among a sample of Estonian, German, and Norwegian public managers to ensure that we could replicate our experiment in these settings. Except for the price levels that were adapted to the Estonian and Norwegian contexts ${ }^{1}$, we did not make any adjustments. Similar to Belgium, we selected the public managers responsible for the environmental department in their municipality and aimed at collecting a minimum of 40 answers per country according to Lancsar and Louviere's (2008) rule of thumb. In Estonia and Norway, we sent the DCE to every municipality. This consists of a population of 77 Estonian public managers and 418 Norwegian public managers. The data collection lasted from June 2018 till July 2018 in Estonia and from September 2018 till November 2018 in Norway. 
However, because Germany is composed of more than 12,000 municipalities, we sent the questionnaire to the municipalities that have more than 20,000 inhabitants and the counties which are also responsible for waste collection. The German sample thus had 901 municipalities and counties. The data collection lasted from July 2018 till October 2018 in Germany. The response rate is 57.1 percent in Estonia, 10.7 percent in Germany, and 27 percent in Norway. Due to the low number of German participants, our sample might not be entirely representative of German public managers responsible for the environment. The German results should therefore be considered with some caution with respect to the representativeness of the sample. Appendix $G$ describes the Estonian, German, and Norwegian sample.

\section{Empirical Strategy}

The choice made by the participants in a given choice set (the dependent variable) is either 0 , for the firm that was not chosen, or 1 , for the firm that was chosen. We consequently conduct a conditional (fixed effects) logistic regression as McFadden (1974) demonstrated that this model is consistent with random utility theory. The conditional logistic regression groups data and then estimates the likelihood relative to each group. We specified the level of the fixed effect at the choice set level, meaning that we grouped together the rows in the data that belong to the same choice set (Ryan et al., 2012). The conditional logistic regression assumes the independence from irrelevant alternatives (IIA). This property, often considered too restrictive, implies that "the unobserved portion of utility for one alternative is unrelated to the unobserved portion of utility for another alternative" (Train 2002, p. 39). To examine whether we can draw analogous conclusions with regards to public managers' valuation of the secondary policy objectives by relaxing the IIA assumption, we conducted, as a robustness check, a mixed logit that allows for preference heterogeneity (Ryan et al., 2012).

\section{Empirical Analysis}

In line with previous public procurement studies (Fuentes-Bargues et al., 2017; Igarashi et al., 2015; Young et al., 2016), we observed that Belgian public managers seem to be more likely to choose a firm that offers the cheapest option. Reducing the price attribute from 270 euros to 250 euros appears to increase the probability of a firm to be selected by 36 percentage points in Belgium (see figure 1). We found similar results in Estonia, Germany, and Norway, further indicating that price seems to continue to be an important criterion in public procurement. 


\section{Figure 1}

Public Managers' Stated Preference for the Criteria - Uptake Rate ${ }^{2}$

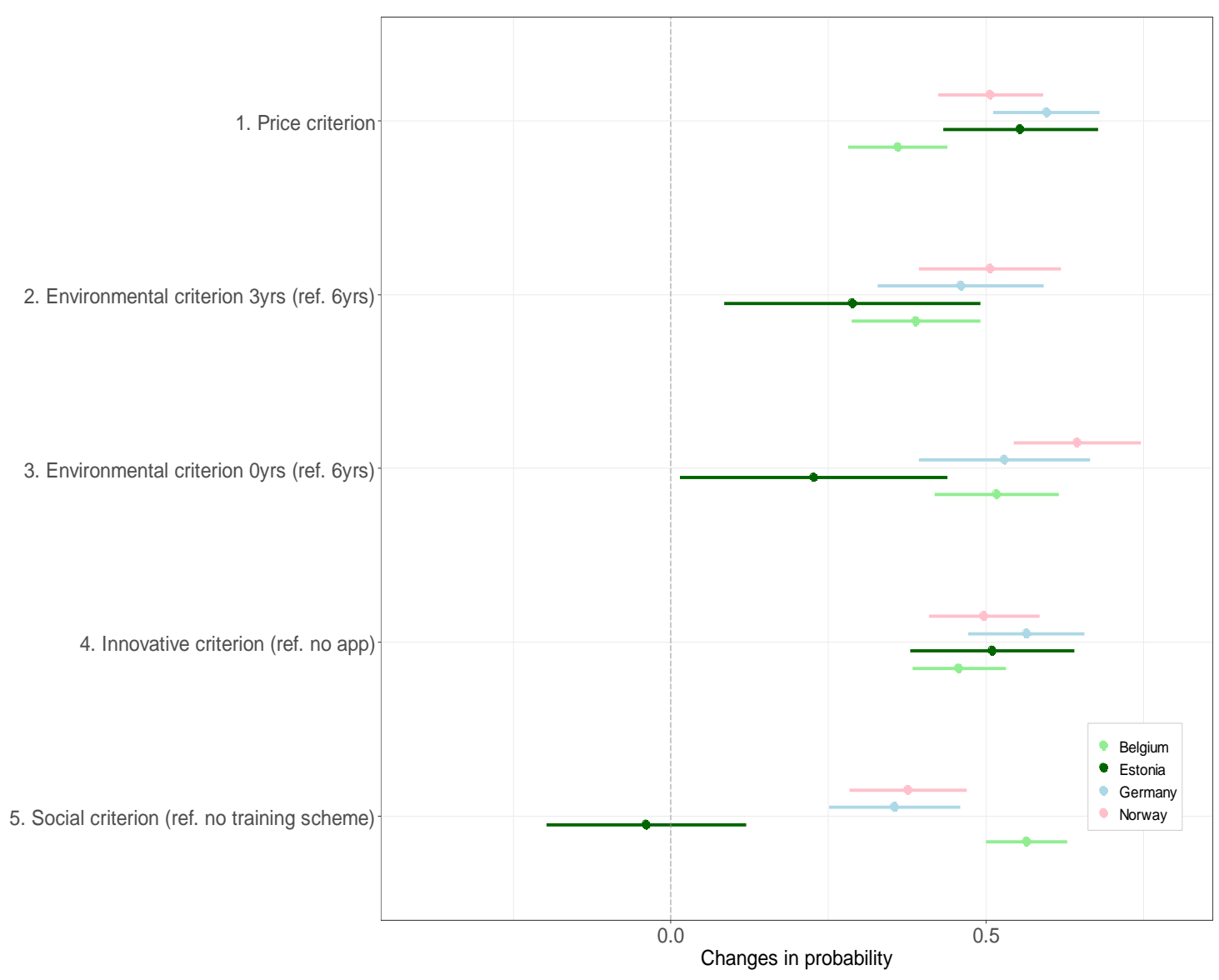

Yet, we also observed that Belgian public managers appear to value secondary policy objectives, suggesting that Belgian public managers seem to be willing to award contracts to firms that offer secondary policy objectives even though these are more expensive later (see figure 1 and 2). With regards to Belgian public managers' valuation of secondary policy objectives, three results need to be highlighted. First, firms involved in a training scheme for long-term unemployed appear to increase their probability of being selected by 56.4 percentage points. Belgian public managers also seem to be willing to pay 33.9 euros more for a firm that is currently involved in a training scheme for long-term unemployed compared to one that is not. Second, compared to a firm with an average age of the fleet of 6 years, a firm with a new fleet of vehicles seems to increase its probability of being selected by 51.7 percentage points. Belgian public managers also appear to be willing to pay 30.3 euros more for a new fleet of vehicles compared to a fleet of vehicles with an average age of 6 years. Lastly, a firm offering a mobile application seems to raise its probability of being chosen by 45.7 percentage points compared to one that does not have a mobile application. Furthermore, Belgian public managers seem to be willing to pay 26.2 euros more for a firm with a mobile application compared to a firm that does not have one. 
Figure 2

Public Managers' Stated Preferences for the Criteria - Marginal Willingness to Pay ${ }^{3}$
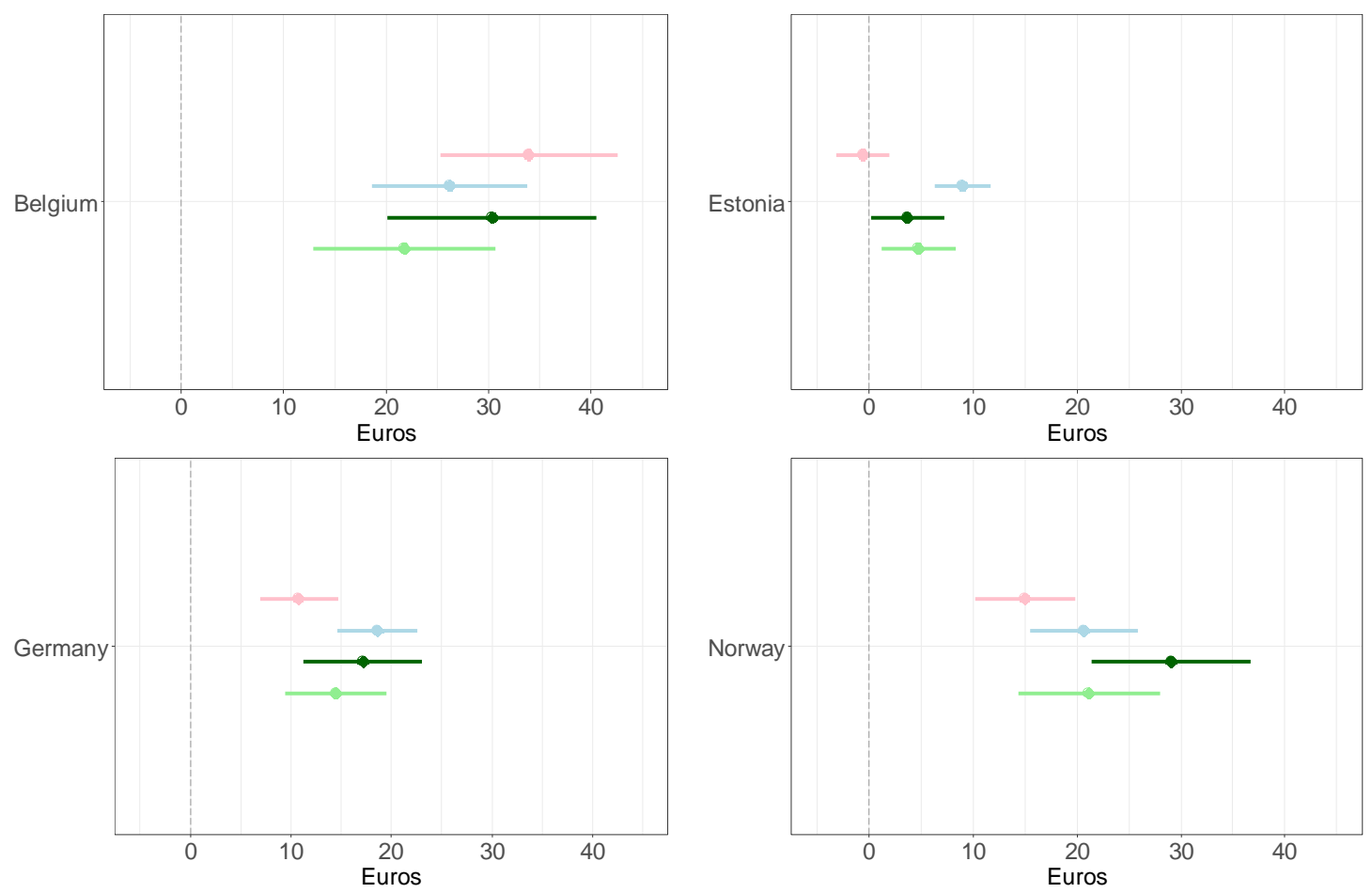

1. Env. criterion (3yrs) - 2. Env. criterion (0yrs) - 3. Inn. criterion $\bullet$ 4. Soc. criterion

Despite some fluctuations across countries with regards to the secondary policy objectives, Estonian, German, and Norwegian public managers seem to be all willing to take secondary policy objectives into consideration, confirming the results we found in Belgium. Whereas German and Norwegian public managers appear to be willing to pay more to support environmental, innovative, and social criteria, Estonian public managers seem to be willing to pay more to promote environmental and innovative criteria. These results suggest that public managers from the four countries appear to value and to be willing to pay more for the secondary policy objectives.

\section{Robustness Check}

The outcome of the mixed logit model points out that Belgian, Estonian, and Norwegian public managers are willing to take secondary policy objectives into consideration. Moreover, the marginal willingness to pay estimates are very similar to the ones derived from the conditional logistic regression (see appendix $\mathrm{H}$ ). As a consequence, these results suggest that relaxing the IIA property in our analysis does not have a major impact on our empirical conclusions. Yet, it should be mentioned that, although the German marginal willingness to pay is very similar to the ones derived from the conditional logistic regression, the mixed logit coefficients are not statistically significant, suggesting that relaxing the IIA property had an effect on the statistical significance of the German estimates. The German results therefore need to be interpreted and considered with some relative caution.

\section{Discussion and Conclusion}

This study has explored how public managers value secondary policy objectives (i.e. environmental, innovative, and social criteria) against price in government contracting for bulky waste collection. Using a DCE, we found, 
in line with previous studies, that price seems to remain an important criterion in public procurement (FuentesBargues et al., 2017; Igarashi et al., 2015; Young et al., 2016). Yet, the results suggest that public managers value secondary policy objectives, and are willing to pay more to support environmental, innovative, and social criteria. The replication studies we conducted in Estonia, Germany, and Norway seem to confirm that public managers are willing to consider secondary policy objective in different administrative settings, strengthening the external validity of our findings.

This study contributes to public procurement research in three distinct ways. First, previous studies tend to exclusively focus on decision-makers' preferences for environmental, innovative, or social criteria but have rarely examined all three secondary policy objectives simultaneously. Our research therefore contributes to giving a more comprehensive perspective on public managers' stated preferences by simultaneously examining their valuation of environmental, innovative, and social criteria.

Second, by quantifying in monetary terms public managers' stated preferences for secondary policy objectives, this study provides further insights on public managers' attitudes in public procurement, a topic that has hitherto received very limited attention in the literature (Grandia \& Meehan, 2017; Trammell et al., 2019). Furthermore, through public managers' marginal willingness to pay, we were able to determine the relative effect of environmental, innovative, and social criteria on public managers' choice. It is also worth noting that except for some studies (Bellé \& Cantarelli, 2018; Jensen \& Pedersen, 2017; Van Puyvelde, Caers, Du Bois, \& Jegers, 2016), DCEs have rarely been conducted in the field of public administration.

Finally, we performed an external validity check to examine whether the results we found in Belgium can be generalizable to other administrative settings. Despite some differences across the countries, we observed that public managers appear not to solely look at price but also seem to consider secondary policy objectives, confirming the results we found in Belgium. By replicating the discrete choice experiment in other contexts, we did not only strengthen the external validity of our research, but also demonstrated that public managers appear to be willing to consider secondary policy objective in different administrative settings.

The findings also have some implications for practice. First, it remains essential that public organizations extend public managers' knowledge on the inclusion of secondary policy objectives in public procurement. This could be done by providing public managers with the necessary trainings on how to evaluate and include secondary policy objectives in public procurement contracts. Second, public managers usually have to deliver public services within tight budgets, but awarding contracts based on secondary policy objectives may put pressure on the budget. Governments have to therefore ensure that, if secondary policy objectives are considered in public procurement contracts, public managers have a sufficient budget to prevent the potential additional costs to be passed on to public service users. Finally, one might wonder whether the demand for secondary policy objectives from government meets the private sector's supply of these secondary policy objectives. Some private firms might indeed be reluctant to integrate environmental, innovative, and social standards as it can increase their overall production costs.

Despite these theoretical and practical contributions, three main limitations need to be highlighted, creating avenues for future research. A first limitation concerns the ecological and construct validity of our study. Public managers' stated preferences are derived based on a hypothetical scenario where real-life decision-making has been simplified and where public managers' stated preferences for the secondary policy objectives do not have real-life consequences. Whereas this threatens the internal validity of our research, we suggest that future studies should aim at comparing public managers' actual and stated preferences by conducting field experiments for instance.

A second limitation is linked to the study sample. As one of the aims of our research was to be as close as possible to real-life decisions, this study surveyed the heads of the environmental department of the municipality because they are responsible for the procurement of waste collection. However, these public managers might be more sensitive to environmental issues, and therefore slightly bias the results of the environmental criterion upward (Baekgaard, 2010). Yet, we argue that it probably mirrors real-life behavior where public managers, responsible for the environment, might be more likely to promote green initiatives. As public managers' preferences or decision-making approach might vary under different type of public services (Kolpakov \& Anguelov, 2020), it is essential for further research to analyze public managers' stated preferences when contracts are awarded in different service areas. 
A final limitation relates to the external validity of our results. Whereas we conducted further analysis in Estonia, Germany, and Norway, these countries are all developed countries. Yet, public managers' valuation of secondary policy objectives might depend on the financial capacity of the country. Therefore, we suggest that further research should aim at examining how public managers value secondary policy objectives in less developed European countries as well as in developing countries outside the European Union.

\section{Notes}

1. As the standard of living is lower in Estonia compared to the other analyzed countries, the price of the service was adapted to 80 euros and 90 euros. In Norway, the price of the service was adjusted to 2400 Norwegian krone ( $\sim 250$ euros) and 2600 Norwegian krone ( 270 euros) as Norway is not part of the Eurozone.

2. Calculations of the $\mathrm{p}$-values and the standard errors were performed by the nlcom-command in Stata. This command bases its calculations on the delta method. The vertical dotted line indicates the value 0 (estimates below 0 are not statistically significant). See appendix I for the coefficients and the standard errors of the conditional logistic regressions.

3. Calculations of the confidence intervals (95 percent) were performed by the nlcom-command in Stata. This command bases its calculations on the delta method. The vertical dotted line indicates the value 0 (marginal willingness to pay estimates below 0 are not statistically significant).

\section{Acknowledgments}

This project has received funding from the European Union's Horizon 2020 research and innovation programme under grant agreement No 726840.

\section{References}

Aizaki, H. (2012). Basic functions for supporting an implementation of choice experiment in R. Journal of Statistical Software, 50(2), 1-24. https://doi.org/2115/57786

Alberg Mosgaard, M. (2015). Improving the practices of green procurement of minor items. Journal of Cleaner Production, 90, 264-274. https://doi.org/10.1016/j.jclepro.2014.11.077

Aldenius, M., \& Khan, J. (2017). Strategic use of green public procurement in the bus sector: Challenges and opportunities. Journal of Cleaner Production, 164, 250257. https://doi.org/10.1016/j.jclepro.2017.06.196

Baekgaard, M. (2010). Self-selection or socialization? A dynamic analysis of committee member preferences. Legislative Studies Quarterly, 35(3), 337-359. https://doi.org/10.3162/036298010792069189

Bellé, N., \& Cantarelli, P. (2018). The role of motivation and leadership in public employees' job preferences: Evidence from two discrete choice experiments. International Public Management Journal, 21(2), 191-212. https://doi.org/10.1080/10967494.2018.1425229

Ben-Akiva, M., \& Lerman, S. R. (1985). Discrete choice analysis: Theory and application to travel demand. Cambridge: MIT Press.

Cooper, R. W., Frank, G. L., \& Kemp, R. A. (2000). A multinational comparison of key ethical issues, helps and challenges in the purchasing and supply management profession: The key implications for business and the professions. Journal of Business Ethics, 23(1), https://doi.org/10.1023/A:1006279112858

de Boer, L. (2017). Procedural rationality in supplier selection: Outlining three heuristics for choosing selection criteria. Management Decision, 55(1), 32-56. https://doi.org/10.1108/MD-08-2015-0373

Edler, J., \& Georghiou, L. (2007). Public procurement and innovation - Resurrecting the demand side. Research Policy, 36(7), 949-963. https://doi.org/10.1016/j.respol.2007.03.003

Edquist, C., \& Zabala-Iturriagagoitia, J. M. (2012). Public procurement for innovation as mission-oriented innovation policy. Research Policy, 41(10), 1757-1769. https://doi.org/10.1016/j.respol.2012.04.022

European Commission. (2011). Buying social. A guide to taking account of social considerations in public procurement. European Union. Retrieved from https://op.europa.eu/en/publication-detail//publication/cb70c481-0e29-4040-9be2c408cddf081f

European Commission. (2016). Buying green! A handbook on green public procurement. European Union. https://doi.org/10.2779/246106

European Commission. (2018). Commission notice: Guidance on innovation procurement. European Union. Retrieved 
from

https:/ /ec.europa.eu/transparency/regdoc/rep/3/ 2018/EN/C-2018-3051-F1-EN-MAIN-PART1.PDF

Fuentes-Bargues, J. L., González-Cruz, M. C., \& González-Gaya, C. (2017). Environmental criteria in the spanish public works procurement process. International Journal of Environmental Research and Public Health, 14(2), 1-18. https://doi.org/10.3390/ijerph14020204

Grandia, J. (2016). Finding the missing link: Examining the mediating role of sustainable public procurement behaviour. Journal of Cleaner Production, 124, 183-190. https://doi.org/10.1016/j.jclepro.2016.02.102

Grandia, J., \& Meehan, J. (2017). Public procurement as a policy tool: Using procurement to reach desired outcomes in society. International Journal of Public Sector Management, 30(4), 302-309. https://doi.org/10.1108/IJPSM-03-2017-0066

Grandia, J., Steijn, B., \& Kuipers, B. (2015). It is not easy being green: Increasing sustainable public procurement behaviour. Innovation, 28(3), 243-260. https://doi.org/10.1080/13511610.2015.1024639

Guevara, C. A., \& Polanco, D. (2016). Correcting for endogeneity due to omitted attributes in discretechoice models: The multiple indicator solution. Transportmetrica A: Transport Science, 12(5), 458-478. https://doi.org/10.1080/23249935.2016.1147504

Hall, P., Löfgren, K., \& Peters, G. (2016). Greening the street-level procurer: Challenges in the strongly decentralized swedish system. Journal of Consumer Policy, 39(4), 467-483. https://doi.org/10.1007/s10603-015-9282-8

Igarashi, M., De Boer, L., \& Michelsen, O. (2015). Investigating the anatomy of supplier selection in green public procurement. Journal of Cleaner Production, 108, 442-450. https://doi.org/10.1016/j.jclepro.2015.08.010

Igarashi, M., de Boer, L., \& Pfuhl, G. (2017). Analyzing buyer behavior when selecting green criteria in public procurement. Journal of Public Procurement, 17(2), 141-186. https://doi.org/10.1108/JOPP-1702-2017-B001

Jaehrling, K. (2015). The state as a 'socially responsible customer'? Public procurement between marketmaking and market-embedding. European Journal of Industrial Relations, 21(2), 149-164. https://doi.org/10.1177/0959680114535316

Jensen, D. C., \& Pedersen, L. B. (2017). The impact of empathy -explaining diversity in street-level decision-making. Journal of Public Administration Research and Theory, 27(3), 433-449. https://doi.org/10.1093/jopart/muw070

Keulemans, S., \& Van de Walle, S. (2017). Costeffectiveness, domestic favouritism and sustainability in public procurement. International Journal of Public Sector Management, 30(4), 328-341.
https://doi.org/10.1108/IJPSM-10-2016-0169

Klesges, L. M., Baranowski, T., Beech, B., Cullen, K., Murray, D. M., Rochon, J., \& Pratt, C. (2004). Social desirability bias in self-reported dietary, physical activity and weight concerns measures in 8- to 10year-old African-American girls: Results from the Girls health Enrichment Multisite Studies (GEMS). Preventive Medicine, 38(SUPPL.), 78-87. https://doi.org/10.1016/j.ypmed.2003.07.003

Kolpakov, A., \& Anguelov, L. G. (2020). Decision-making approaches to contracting out. Journal of Strategic Contracting and Negotiation, 20(10), 1-19. https://doi.org/10.1177/2055563620918811

Lancsar, E., \& Louviere, J. (2006). Deleting "irrational" responses from discrete choice experiments: A case of investigating or imposing preferences? Health Economics, 15(8), 797-811. https://doi.org/10.1002/hec.1104

Lancsar, E., \& Louviere, J. (2008). Conducting discrete choice experiments to inform healthcare decision making: A user's guide. PharmacoEconomics, 26(8), 661-677. https://doi.org/10.2165/00019053200826080-00004

Leal Filho, W., Skouloudis, A., Brandli, L. L., Salvia, A. L., Avila, L. V., \& Rayman-Bacchus, L. (2019). Sustainability and procurement practices in higher education institutions: Barriers and drivers. Journal of Cleaner Production, 231, 1267-1280. https://doi.org/10.1016/j.jclepro.2019.05.202

Loosemore, M. (2016). Social procurement in UK construction projects. International Journal of Project Management, 34(2), 133-144. https://doi.org/10.1016/j.ijproman.2015.10.005

Louviere, J. J., Flynn, T. N., \& Carson, R. T. (2010). Discrete choice experiments are not conjoint analysis. Journal of Choice Modeling, 3(3), 57-72. https://doi.org/10.1016/S1755-5345(13)70014-9

Manski, C. F. (1977). The structure of random utility models. Theory and Decision, 8(3), 229-254. https://doi.org/10.1007/BF00133443

McCrudden, C. (2004). Using public procurement to achieve social outcomes. Natural Resources Forum, 28(4), 257-267. https://doi.org/10.1111/j.14778947.2004.00099.x

McFadden, D. (1974). Conditional logit analysis of qualitative choice behavior. In P. Zarembka (Ed.), Frontiers in Econometrics (pp. 105-142). New York: Academic Press.

Morettini, S. (2011). Public procurement and secondary policies in EU and global administrative law. In E. Chiti \& B. G. Mattarella (Eds.), Global Administrative Law and EU Administrative Law: Relationships, Legal Issues and Comparison (pp. 187-209). Berlin Heidelberg: Springer Berlin Heidelberg.

Mouraviev, N., \& Kakabadse, N. K. (2015). Public-private partnership's procurement criteria: The case of managing stakeholders' value creation in 
Kazakhstan. Public Management Review, 17(6), 769790.

https://doi.org/10.1080/14719037.2013.822531

OECD. (2018). Contingent valuation method. In CostBenefit Analysis and the Environment Further Developments and Policy Use (pp. 85-127). Paris. https://doi.org/doi.org/10.1787/97892640851697-en This

OECD. (2019). Government at a Glance 2019. OECD. Retrieved from https://www.oecdilibrary.org/docserver/8ccf5c38-

en.pdf?expires $=1594214798 \& \mathrm{kid}=\mathrm{id} \&$ accname $=$ gue st\&checksum=7DDAD2458E812FEA960722A1A 4466443

Pollitt, C., \& Bouckaert, G. (2017). Public Management Reform: A Comparative Analysis into the Age of Austerity (Fourth Edi). Oxford: Oxford University Press.

Preuss, L., \& Walker, H. (2011). Psychological barriers in the road to sustainable development: Evidence from public sector procurement. Public Administration, 89(2), 493-521. https://doi.org/10.1111/j.14679299.2010.01893.x

Ryan, M., Kolstad, J. R., Rockers, P. C., \& Dolea, C. (2012). User Guide With Case Studies: How to Conduct a Discrete Choice Experiment for Health Workforce Recruitment and Retention in Remote and Rural Areas. World Health Organization. Retrieved from https://www.who.int/hrh/resources/dceguide/en /

Simon, H. A. (1955). A behavioral model of rational choice. The Quarterly Journal of Economics, 69(1), 99118. https://doi.org/10.2307/1884852

Sönnichsen, S. D., \& Clement, J. (2019). Review of green and sustainable public procurement: Towards circular public procurement. Journal of Cleaner Production, 245, 1-18. https://doi.org/10.1016/j.jclepro.2019.118901

Testa, F., Iraldo, F., Frey, M., \& Daddi, T. (2012). What factors influence the uptake of GPP (green public procurement) practices? New evidence from an
Italian survey. Ecological Economics, 82, 88-96. https://doi.org/10.1016/j.ecolecon.2012.07.011

Thomson, J., \& Jackson, T. (2007). Sustainable procurement in practice: Lessons from local government. Journal of Environmental Planning and Management, $\quad 50(3), \quad 421-444$. https://doi.org/10.1080/09640560701261695

Train.(2002). Discrete choice methods with simulation, Cambridge University Press.

Trammell, E., Abutabenjeh, S., \& Dimand, A.-M. (2019). A review of public administration research: Where does public procurement fit in? International Journal of Public Administration, 43(8), 1-13. https://doi.org/10.1080/01900692.2019.1644654

Uyarra, E., Edler, J., Garcia-estevez, J., Georghiou, L., \& Yeow, J. (2014). Barriers to innovation through public procurement: A supplier perspective. Technovation, 34(10), 631-645. https://doi.org/10.1016/j.technovation.2014.04.00 3

Van Puyvelde, S., Caers, R., Du Bois, C., \& Jegers, M. (2016). Managerial objectives and the governance of public and non-Profit Organizations. Public Management Review, 18(2), 221-237. https://doi.org/10.1080/14719037.2014.969760

Walker, H., \& Brammer, S. (2009). Sustainable procurement in the United Kingdom public sector. Supply Chain Management: An International Journal, 14(2), 128-137. https://doi.org/10.1108/13598540910941993

Walker, H., Di Sisto, L., \& McBain, D. (2008). Drivers and barriers to environmental supply chain management practices: Lessons from the public and private sectors. Journal of Purchasing and Supply Management, 14(1), 69-85. https://doi.org/10.1016/j.pursup.2008.01.007

Young, S., Nagpal, S., \& Adams, C. A. (2016). Sustainable procurement in australian and UK universities. Public Management Review, 18(7), 993-1016. https://doi.org/10.1080/14719037.2015.1051575 


\section{Appendix}

\section{Appendix A. Discrete Choice Experiment Hypothetical Scenario and Instructions}

\section{In this section, we ask you to answer 6 questions based on the following hypothetical scenario:}

Imagine, even if waste collection might not be your area of responsibility, that the town council of the municipality you are working for has just decided to change to a new way of collecting bulky waste items. The municipality will give this task to an external actor. If you were to choose between the following firms, in looking at all the firm characteristics, which one of these firms would be, in your opinion, the optimum bulky waste items collector?

In the next six questions, you are required to choose which one of the two described firms you would prefer. The firms have different characteristics. Please read the following remarks carefully before answering the questions.

When answering the six following questions:

- Assume that the non-described characteristics are the same for every firm.

- Answer all questions assuming that the two described firms are the only available options and that you are required to choose one of them.

- Answer the questions assuming that your municipality is entirely responsible for waste collection, and not the inter-municipal association.

There are no right or wrong answers. 


\section{Appendix B. Initial List of Attributes and Levels Developed after the Desk Research}

\begin{tabular}{|c|c|}
\hline Attributes & Levels \\
\hline $\begin{array}{l}\text { Cost per household (this cost rep- } \\
\text { resents the cost of collecting and } \\
\text { treating waste) }\end{array}$ & $\begin{array}{l}\text { - } \quad \text { The cost is } 64 \text { EUR per household. } \\
\text { - } \quad \text { The cost is } 82 \text { EUR per household. } \\
\text { - } \quad \text { The cost is } 101 \text { EUR per household. }\end{array}$ \\
\hline $\begin{array}{l}\text { Percentage of decrease / increase } \\
\text { in the firms' turnover compared to } \\
\text { the previous year }\end{array}$ & $\begin{array}{l}\text { - The firm's turnover has decreased by } 5 \% \text { compared to } \\
\text { last year. } \\
\text { - The firm's turnover has remained stable compared to last } \\
\text { year. } \\
\text { - The firm's turnover has increased by } 5 \% \text { compared to } \\
\text { last year. }\end{array}$ \\
\hline Type of fuel used by firms' trucks & $\begin{array}{l}\text { - } \quad \text { The firm has electric trucks in its fleet. } \\
\text { - } \quad \text { The firm does not have electric trucks in its fleet. }\end{array}$ \\
\hline $\begin{array}{l}\text { The firm has won an environmen- } \\
\text { tal award }\end{array}$ & $\begin{array}{l}\text { - } \quad \text { The firm won an environmental award in X. } \\
\text { - } \quad \text { The firm won an environmental award in X. }\end{array}$ \\
\hline Employees' working conditions & $\begin{array}{l}\text { - The working conditions of the firm's employees are bad. } \\
\text { - The working conditions of the firm's employees are av- } \\
\text { erage. } \\
\text { - The working conditions of the firm's employees are ex- } \\
\text { cellent. }\end{array}$ \\
\hline $\begin{array}{l}\text { The firm is involved in a project } \\
\text { that promotes the professional in- } \\
\text { tegration of vulnerable groups }\end{array}$ & $\begin{array}{l}\text { - The firm is currently involved in a training program ded- } \\
\text { icated to the long-term unemployed. } \\
\text { - The firm is not currently involved in a training program } \\
\text { dedicated to the long-term unemployed. }\end{array}$ \\
\hline Smart trucks & $\begin{array}{l}\text { - } \quad \text { The firm has smart trucks in its fleet. } \\
\text { - } \quad \text { The firm does not have smart trucks in its fleet. }\end{array}$ \\
\hline Application & $\begin{array}{l}\text { - The firm offers a mobile application for service users. } \\
\text { - The firm does not offer a mobile application for service } \\
\text { users. }\end{array}$ \\
\hline
\end{tabular}




\section{Appendix C. List of Attributes and Levels}

\begin{tabular}{|c|c|c|c|}
\hline & Level 1 & Leve1 2 & Leve1 3 \\
\hline Price & $\begin{array}{l}\text { The price per ton is } 250 \\
\text { EUR. }\end{array}$ & $\begin{array}{l}\text { The price per ton is } 270 \\
\text { EUR. }\end{array}$ & \\
\hline $\begin{array}{l}\text { Environmental } \\
\text { criterion }\end{array}$ & $\begin{array}{l}\text { The average age of the } \\
\text { fleet of vehicles is } 6 \\
\text { years. }\end{array}$ & $\begin{array}{l}\text { The average age of the } \\
\text { fleet of vehicles is } 3 \\
\text { years. }\end{array}$ & $\begin{array}{l}\text { The average age of the } \\
\text { fleet of vehicles is } 0 \\
\text { years (an entire new } \\
\text { fleet will be put into } \\
\text { circulation). }\end{array}$ \\
\hline Innovative criterion & $\begin{array}{l}\text { The firm does not offer } \\
\text { a mobile application for } \\
\text { smart-phones for ser- } \\
\text { vice users. }\end{array}$ & $\begin{array}{l}\text { The firm offers a mo- } \\
\text { bile application for } \\
\text { smart-phones for ser- } \\
\text { vice users (this mobile } \\
\text { application has a calen- } \\
\text { dar, informs on pick-up } \\
\text { days and offers a con- } \\
\text { tact tool,...). }\end{array}$ & \\
\hline Social criterion & $\begin{array}{l}\text { The firm is not cur- } \\
\text { rently involved in a } \\
\text { training scheme for } \\
\text { long-term unemployed. }\end{array}$ & $\begin{array}{l}\text { The firm is currently in- } \\
\text { volved in a training } \\
\text { scheme for long-term } \\
\text { unemployed. }\end{array}$ & \\
\hline
\end{tabular}




\section{Appendix D. Example of a Choice Set Displayed to the Participants}

Which firm do you prefer?

\begin{tabular}{|c|c|c|}
\hline & Firm 1 & Firm 2 \\
\hline Social criterion & $\begin{array}{l}\text { The firm is currently involved } \\
\text { in a training scheme for long- } \\
\text { term unemployed. }\end{array}$ & $\begin{array}{l}\text { The firm is not currently in } \\
\text { volved in a training scheme for } \\
\text { long-term unemployed. }\end{array}$ \\
\hline Environmental criterion & $\begin{array}{l}\text { The average age of the fleet of } \\
\text { vehicles is } 3 \text { years. }\end{array}$ & $\begin{array}{l}\text { The average age of the fleet of } \\
\text { vehicles is } 6 \text { years. }\end{array}$ \\
\hline Innovative criterion & $\begin{array}{l}\text { The firm does not offer a mo- } \\
\text { bile application for smart- } \\
\text { phones for service users. }\end{array}$ & $\begin{array}{l}\text { The firm offers a for smart- } \\
\text { phones for service users (this } \\
\text { mobile application has a calen- } \\
\text { dar, informs on pick-up days } \\
\text { and offers a contact tool, ...). }\end{array}$ \\
\hline Price & The price per ton is 270 EUR. & The price per ton is 250 EUR. \\
\hline
\end{tabular}

Please only tick one box.
○ I prefer firm 1
$\circ$ I prefer firm 2 
Appendix E. Choice Sets and Attributes (Block 1)

\begin{tabular}{|l|l|l|l|l|l|}
\hline & & Price & Environmental & Innovative & Social \\
\hline Choice set 1 & Firm 1 & Highest price & No app & New fleet & Not involved \\
\cline { 2 - 6 } & Firm 2 & Lowest price & App & 3 years & Involved \\
\hline Choice set 2 & Firm 1 & Lowest price & No app & 3 years & Not Involved \\
\cline { 2 - 7 } & Firm 2 & Highest price & App & 6 years & Involved \\
\hline Choice set 3 & Firm 1 & Highest price & No app & 6 years & Involved \\
\cline { 2 - 7 } & Firm 2 & Lowest price & App & New fleet & Not involved \\
\hline Choice set 4 & Firm 1 & Highest price & App & New fleet & Not involved \\
\cline { 2 - 7 } & Firm 2 & Lowest price & No app & 3 years & Involved \\
\hline Choice set 5 & Firm 1 & Lowest price & No app & 6 years & Not involved \\
\cline { 2 - 6 } & Firm 2 & Highest price & App & New fleet & Involved \\
\hline Choice set 6 & Firm 1 & Lowest price & App & 3 years & Not involved \\
\cline { 2 - 6 } & Firm 2 & Highest price & No app & 6 years & Involved \\
\hline
\end{tabular}


Appendix E. Choice Sets and Attributes (Block 2) (Continued)

\begin{tabular}{|l|l|l|l|l|l|}
\hline & & Price & Environmental & Innovative & Social \\
& & & criterion & criterion & criterion \\
\hline Choice set 7 & Firm 1 & Lowest price & App & New fleet & Involved \\
\cline { 2 - 6 } & Firm 2 & Highest price & No app & 3 years & Not involved \\
\hline Choice set 8 & Firm 1 & Highest price & No app & 3 years & Involved \\
\cline { 2 - 7 } & Firm 2 & Lowest price & App & 6 years & Not involved \\
\hline Choice set 9 & Firm 1 & Lowest price & No app & New fleet & Involved \\
\cline { 2 - 7 } & Firm 2 & Highest price & App & 3 years & Not involved \\
\hline Choice set 10 & Firm 1 & Highest price & App & 3 years & Involved \\
\cline { 2 - 7 } & Firm 2 & Lowest price & No app & 6 years & Not involved \\
\hline Choice set 11 & Firm 1 & Highest price & App & 6years & Not involved \\
\cline { 2 - 6 } & Firm 2 & Lowest price & No app & New fleet & Involved \\
\hline & Firm 2 & Highest price & No app & New fleet & Not involved \\
\hline
\end{tabular}


Appendix F. Balance Checks of Randomization - Block 1 against Block 2

\begin{tabular}{lllll}
\hline \hline & Belgium & Estonia & Germany & Norway \\
\hline Age & -0.005 & -0.021 & -0.020 & -0.033 \\
& $(0.028)$ & $(0.043)$ & $(0.035)$ & $(0.029)$ \\
Gender (ref. Females) & $0.552^{+}$ & 0.080 & 0.260 & 0.649 \\
& $(0.325)$ & $(0.744)$ & $(0.513)$ & $(0.523)$ \\
Education (ref. & 0.495 & -1.263 & - & -0.496 \\
no University degree) & $(0.694)$ & $(1.851)$ & - & $(0.487)$ \\
Tenure & & & & 0.002 \\
& -0.004 & 0.054 & 0.026 & $(0.021)$ \\
& $(0.028)$ & $(0.049)$ & $(0.025)$ & 113 \\
\hline $\begin{array}{l}\text { Number of observa- } \\
\text { tions }\end{array}$ & 161 & & & 0.027 \\
Pseudo R & 0.017 & 0.030 & 0.011 & \\
\hline Notes: logistic regression coefficients (standard errors).***p $<0.001, * * \mathrm{p}<0.01, * \mathrm{p}<0.05,{ }^{+} \mathrm{p}<0.1$. \\
\end{tabular}

Notes: logistic regression coefficients (standard errors). ${ }^{* * *} \mathrm{p}<0.001,{ }^{* *} \mathrm{p}<0.01,{ }^{*} \mathrm{p}<0.05,{ }^{+} \mathrm{p}<0.1$. 
Appendix G. Characteristics of Public Managers - Age, Gender, Education and Tenure

\begin{tabular}{lllll}
\hline \hline & Belgium & Estonia & Germany & Norway \\
\hline Age & & & & \\
Mean & 44.98 & 46.05 & 54.14 & 52.35 \\
Standard deviation & 9.60 & 11.21 & 7.77 & 8.42 \\
Minimum & 24 & 27 & 28 & 29 \\
Maximum & 67 & 70 & 65 & 69 \\
Gender & & & & \\
Female & $53.42 \%$ & $31.82 \%$ & $19.79 \%$ & $22.12 \%$ \\
Male & $46.58 \%$ & $68.18 \%$ & $80.21 \%$ & $77.88 \%$ \\
& & & & \\
Education & & & & $18.58 \%$ \\
No university degree & $6.83 \%$ & $6.82 \%$ & & $81.42 \%$ \\
University degree & $93.17 \%$ & $93.18 \%$ & $100 \%$ & \\
Tenure & & & & 20.81 \\
Mean & 16.74 & 14.82 & 25.85 & 0 \\
Standard deviation & 9.67 & 8.94 & 10.71 & 44 \\
Minimum & 0 & 1 & 1 & \\
Maximum & 39 & 48 & 47 & \\
Number of observations & 161 & 44 & 96 & \\
& & & & \\
\hline
\end{tabular}




\section{Appendix H. Public Managers' Stated Preferences for the Criteria - Marginal Willingness to Pay}

\section{(Derived from the Mixed Logit Model)}
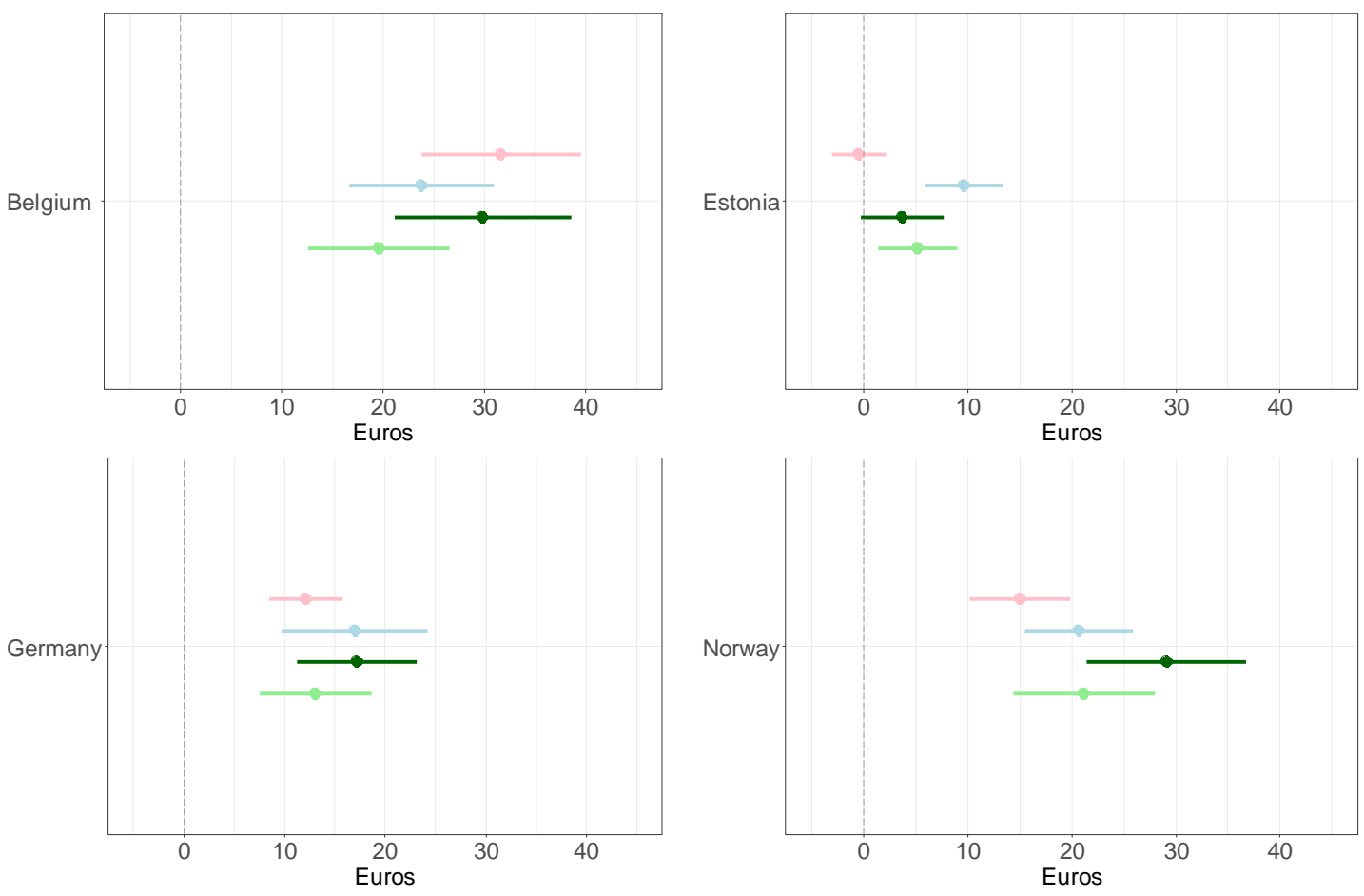

1. Env. criterion (3yrs) $\bullet$ 2. Env. criterion $(0 y r s) \bullet 3$. Inn. criterion $\bullet 4$. Soc. criterion

Notes: Marginal willingness to pay estimates derived from the mixed logit model. In the mixed logit, price has been specified as fixed and the secondary policy objectives as random. Number of Halton draws: 500. Calculations of the confidence intervals ( 95 percent) were performed by the nlcom-command in Stata. This command bases its calculations on the delta method. The vertical dotted line indicates the value 0 (marginal willingness to pay estimates below 0 are not statistically significant). 
Appendix I.

Public Managers' Stated Preferences for the Criteria - Conditional Logistic Regression

\begin{tabular}{|c|c|c|c|c|}
\hline & Belgium & Estonia & "Germany & Norway \\
\hline \multirow{2}{*}{$\begin{array}{l}\text { Price criterion } \\
\text { ref. lowest } \\
\text { price }\end{array}$} & $-0.038 * * *$ & $-0.125^{* * *}$ & $-0.069 * * *$ & $-0.006^{* * *}$ \\
\hline & $(0.005)$ & $(0.018)$ & $(0.007)$ & $(0.0006)$ \\
\hline \multirow{2}{*}{$\begin{array}{c}\text { Environmental } \\
\text { criterion ( } 3 \mathrm{yrs}) \\
\text { ref. } 6 \text { years }\end{array}$} & $0.821 * * *$ & $0.592^{* *}$ & $0.994 * * *$ & $1.116^{* * *}$ \\
\hline & $(0.123)$ & $(0.226)$ & $(0.170)$ & $(0.154)$ \\
\hline \multirow{2}{*}{$\begin{array}{c}\text { Environmental } \\
\text { criterion (0yrs) } \\
\text { ref. } 6 \text { years }\end{array}$} & $1.143^{* * *}$ & $0.461 *$ & $1.178^{* * *}$ & $1.534 * * *$ \\
\hline & $(0.137)$ & $(0.228)$ & $(0.192)$ & $(0.176)$ \\
\hline \multirow{2}{*}{$\begin{array}{l}\text { Innovative } \\
\text { criterion } \\
\text { ref. no app }\end{array}$} & $0.988 * * *$ & $1.126^{* * *}$ & $1.277 * * *$ & $1.090 * * *$ \\
\hline & $(0.095)$ & $(0.180)$ & $(0.138)$ & $(0.119)$ \\
\hline \multirow{2}{*}{$\begin{array}{l}\text { Social criterion } \\
\text { ref. no } \\
\text { training } \\
\text { scheme }\end{array}$} & $1.279 * * *$ & -0.077 & $0.743^{* * *}$ & $0.791 * * *$ \\
\hline & $(0.096)$ & $(0.162)$ & $(0.122)$ & $(0.110)$ \\
\hline \multirow{2}{*}{$\begin{array}{l}\text { Alternative } \\
\text { specific constant } \\
\text { (ASC) }\end{array}$} & 0.117 & -0.085 & -0.011 & 0.104 \\
\hline & $(0.092)$ & $(0.156)$ & $(0.123)$ & $(0.111)$ \\
\hline $\begin{array}{l}\text { Number of } \\
\text { observations }\end{array}$ & 1,932 & 528 & 1,152 & 1,356 \\
\hline $\begin{array}{l}\text { Number of public } \\
\text { managers }\end{array}$ & 161 & 44 & 96 & 113 \\
\hline Pseudo R ${ }^{2}$ & 0.388 & 0.304 & 0.434 & 0.414 \\
\hline
\end{tabular}

